\title{
建築設計プロセスにおける幾何的知識の表現に関する研究 REPRESENTING GEOMETRIC KNOWLEDGE IN ARCHITECTURAL DESIGN PROCESS
}

\author{
渡辺 俊* \\ Shun WATANABE
}

\begin{abstract}
Geometric knowledge is essential to architectural design. Every geometric object used in current CAD/CG systems is primary defined by vertices. But most of geometric objects in architectural design are produced by previously defined objects and geometric procedures. To follow the designer's decision making process, what we have to store in intelligent CAAD systems are the desiger's decisions expressed as procedures which imply the geometric facts, restrictions, and contexts.

GDL(Geometric Decision Library) is designed to express architectural designer's geometric decisions making process naturally, and implemented on Smalltalk environment. GDL constitutes geometric decision tree(network) for architectural design, and reconsideration of geometric decision for an architectural design extracts each restrictions, and can maintain total geometry in every state of architectural design process.
\end{abstract}

Keywords : computing geometry, artificial intelligence, knowledge representation, $C A D$ 計算幾何学, 人工知能, 知識表現, $C A D$

\section{1. はじめに}

設計プロセスとは决定ブロセスであるとも言われるように、知的 設計支援システム文 5,7$)$ の実現においては、設計プロセスにおける デザイン上の様々な決定を、いが人間の思考・記憶方法により近 らかたちで表現し蓄えるてとができるかが重要となる注1)。今日、 これらを実現する具体的枠組みとして、情報処理の分野で主流とな りつつあるオブジェクト指向分析 (Object-Oriented Analysis)の 方法論 $\left.{ }^{2} 2\right)$ K基ゔき設計要素をオブジェクトと捕らえ、これら要 素間の関係により設計対象の人工物を表現する研究が盛んK行わ れるよらになった注3)。これらの研究では、単に設計要素の形態情 報を表現するK留まらず、そのオブジェクトが内包する幾何的属性 以外の情報をも取り扱らてとに主眼が置かれているが、一方そてで 利用される幾何的表現自体は、既存の CAD・CG システムに見ら

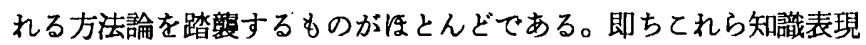
に基づくモデルにおいても、デザインに登場する全ての幾何的决定 は、個別の幾何オブジェクトの存在を具体的座標値として、静的に 還元されているのである。

例えば、M.Gross が提案したシステムでは、まず建築要素を示 唆する線分や長方形といった幾何図形を入力し、それらの図形間 の制約を”関係メニュー”から選択・適応するといらアプローチを 採用した文6)。また高本らは、設計者の思考過程において観察され る建築要素間の関係を大きく部材構成・隣接関係・位置関係といら 3 つの設計ルールとして整理し、同様のアプローチで商用 CAD シ
ステムを拡張し実装した文10)。これらの研究はいずれす、制約ブ ログラミングの考え方に基づ、建築要素間の幾何的制約を図形間 の制約として、既存の CAD の延長線上に付加的に表現したもの であった。

これに対し筆者らは、知的建策設計支援システムを実現する ための建築モデルの基本的枠組みとして AKM (Architectural Knowledge-representation Model) を提案し、システムのプロト タイブを作成してをた文11,12)。AKM では、特定の坐標值に固定 された建築要素の形態表現が設計プロセスのダイナミズムを制約す るとの認識から、既存の $\mathrm{CAD} ・ \mathrm{CG}$ システムK見られるよらな形 態表現モデルを建築オブジェクトの属性情報として恒久的に保持 させることをあえて切り捨ててきた。つまり AKM は、建築デザ インにおける階・部屋・柱・梁などといった具体的な構成要素間の 制約に関する認知科学的視点から見た表現を、主に考慮したもので あった。他方、建築設計における幾何的制約あるいは秩序を表現す るものは、水平方向については柱の位置を特定するための通り心才 ブジェクトのみであり、垂直方向については階オブジェクトがその 幾何的秩序の代用となってた。

建築設計は、他の工学における設計分野と比較して形態志向が強 く、設計仕様から導かれる設計要素の構成においても、機能的秩序 むさるととながら幾何的秩序を優先する傾向が強い分野である。し かし、通り心による順序付けのみを拠り所とするモデルだけでは、 表見可能な建築形態に対する制約が大きいととは想像に易い。形態

\footnotetext{
$*$ 筑波大学社会工学系 講師・工博
} 
表現における自由度をより高めるためには、幾何学それ自体を知識 として表現できかつデザイン思考とも親和性の高いモデルが、先の ような建築モデルと供に必要である。

一方、コンピュータを単に狭義の数值計算の道具として利用する のではなく、より広義の数学的計算を行わせるための数式処理の研 究が、人工知能研究の一分野として古くから行われてきた。てれら の成果として提供される数式処理システムを利用するてとにより、 幾何的要素を具体的座標値に還元する前の関数の段階で処理するて とが可能となる文4)。しかし、関数のレベルで処理が行われるとと 自体は、それぞれの式が個別の幾何的意味や CAD。CGKおける 形態の表現と直接結びつくものでもなければ、個別の幾何オブジェ. クトを明示したり示唆するものでもない。今日、まだ幾何図形を幾 何本来の方法論に基づき表現可能なシステムは存在しない。

\section{2. 研究目的}

本研究の目的は、建築設計プロセスにわける幾何的制約あるい は秩序に関する决定が、知識工学により指摘される人間の思考・ 記憶方法に従ったかたちで表現可能なモデルを提案するてとであ る。これに基づき構築されるジオメトリックライブラリは、今日の $\mathrm{CAD} ・ \mathrm{CG}$ システムが拠り所とするグラフィックライブラリと呼 ばれるむのが表示メディアへの出力を主として考慮した構造体・関 数群であるのとは対照である。

\section{3. 設計における幾何学}

建築デザイン注4) が持つ幾何的特性を分析する研究は、建築史 学や建築計画理論などでも様々なアプローチがなされてきたが、ま さにそてで指摘されるととは、形態記述に観察される建築要素の椣 成が平行・交差・対称といった幾何的事実・秩序を拠り所とした述 語により説明されているととである。同様に、建築設計プロセスに おける形態試行は幾何的操作の積み重ねであり、単なる建築要素の 一元的羅列による表現ではなく、建築形態を構成する文法に着目し たデザイン操作の研究 (Shape Grammar) む行われるよらになっ

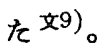

一方、今日の $\mathrm{CAD}$ ・CG システムKおいて利用されている幾何 オブジェクトは、頂点 (vertices) を基準に考えられてきた。つま り、まず静的な構造体としての $P(x, y)$ あるいは $P(x, y, z)$ によ り定義される 2 次元および 3 次元上の点の存在を仮定し、てれを して他の全ての幾何オブジェクの根元としてきたのである。例 えぱ、直線を示すオブジェクトは始点と終点といら二つの頂点によ り定義され、平面を示すオブジェクトは、三つ以上の頂点の集合に より定鋨されるのである。これらを正確に表現するならば、数学的 意味での直線 (Line) や平面 (Plane) は存在せず、線分 (Segment) や面分 (Domain) が存在するのみであると言える。

一般にデザインにおける幾何的意味での决定とは、ある面とある 面が平行であるという事実であり、個々の面を具体的に構成する頂 点列ではない。あるいは、あるデザイン上で参照する点が補助線と 補助線の交点として生成されるとい5事実であり、その点が結果的 に持つであろら具体的な 3 次元座標值ではない。デザインを棈成 する大半の幾何オブジェクトは、他の幾何オブジェクトを找り所に 手続き的に生成されたものであり、こてで保存すべき設計者の决定
とは、それが生成されるべき背景としての手続き自体とするのが理 想である。

これに対し、幾つかの CAD システムでは、既存の枠組みの中 で、幾何的决定を入力したコマンドの時系列的スタックとして付 加的飞保存する方法が古くから試行されてきた注5)。乙の方法は一 見、設計者の决定プロセスを保存しているよらに思われる。しか し、ての方法だけでは、単に以前のデザインの状態に戻るてとがで きるだけで、决定の変更が幾何的要素間の制約により関連する他要 素に伝播するといら設計行為本来に見られる幾何的処理が実現でき ない。例えば、設計ブロセスにおいて二つの平面の交差部分として 意図された直線は、いずれの平面の移動においても応分の影響をう けるのが自然である。同様に二つの直線の交点は、直線の移動によ り適宜その位置が変更されるであろら。

建築設計プロセスの中でデザインのコンテクストK必要な幾何オ ブジェクトを定義した手続をの構造そのものが、建築設計における 幾何的意味での決定と呼べるものである。しかし、今日コンピュー タにより幾何学を扱ら方法論では、てれらの决定の構造自体は保存 すべき対象とされず、手続きにより変換された結果としての具体的 数値のみを蓄積するといらモデルを追いかけてきた。これは、多く のコンピュータ言語自体が、手続とデータを明示的に分離するパラ ダイムを採用してきたてとにす起因すると考えられる。

一方LISP K代表される人工知能向言語と呼ばれる環境では、 手続き(プログラム) そのものをデータとして扱らてとが可能であ る。すなわちてれらの言語は、手続き自体を変数に割り当てたり、 その任意の時点での具体的值を動的に得られる仕組みを有してい る。設計における幾何学のために必要なモデルとは、グラフィック を表現するための效率的モデルもさるととながら、てのよらなパラ ダイムに基づき幾何的决定を手続きの集合体として表現し保存でき るモデルである。

以上の考察に基づき、GDL(Geometric Decision Library)を 提案する。なお、以下に示すプログラムを示唆する記述文は全て Smalltalk 言語注6) 上に実装された具体的ライブラリにおいて、 そのまま実行可能なコードに基づくものである。

\section{4. 空間幾何オブジェクトの表現}

全ての空間幾何オブジェクトを座標値の集合に還元して表現・保 存する方法論は、どの様に複雑な操作刘象でも基本的に 3 次元座 䅺值 $(x, y, z)$ のみであるといら箪純な棈造を保証している。てれ は、境界のはっきりした人工物の形状のみを表現する、あるいはそ の延長線上で幾何的㙅作 $(4 \times 4$ の行列変換 $)$ を加えるには有効な アプローチである。しかし、特に建築設計プロセスで必要とされる ”空間的秩序を示す制約としての幾何”を表現するには、ての座標 值還元モデルだけでは困難である。なぜなら、こてで表現したいの は、建築的実体としての面や線ではではならからである。つまり、 秩序とは個別の要素の具体的形態を表すのではない一方、代用され る計算幾何図形のデータ構造はデザインに意図された本来の意味か ら解離しているからである。

GDL においては、まず様々な建築設計プロセスにおいて設計対 象の幾何的制約を記述するために最低限必要とされる空間幾何オブ 
ジェクトを、坐標値の集合と限定せず、それ本来の幾何的・数学的 特性により記述するてとを試みる。数学において空間を表現する基 本要素としてはべクトル $V$ Kよる表現が有効であり、人工物の形 態にわける幾何的制約の表現に最低限必要な直線・平面といった基 本図形が、それぞれべクトル空間における関数として表現できるて とは広く認められるとてろである。ただし、てれは空間のモデルと してベクトル空間を採用するといらことであり、幾何オブジェクト の表現が全て位置べクトル (座標値)の集合に還元されることとは 異なる。

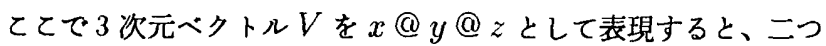
の位置ベクトルにより示される点を通過する直線は、以下の式、

Line at: $1 @ 0 @-1$ and: $0 @ 1 @ 1$

を評価する注7）ととにより、

$$
(\mathrm{x}-1) /-1=(\mathrm{y}) / 1=(\mathrm{z}+1) / 2
$$

なる直線オブジェクト(インスタンス)がその㞍り值として生成さ れる。ててで大文字で始まるシンボル (Line) はオブジェクト指向 Kおけるクラスを、コロンを含むシンボル (at:and:) はメッセージ をSmalltalk の慣例飞従い表現するものとし、(2) К示されるよ らなインスタンスの関数表記はそれが内包する手続き (printOn:) によりその表示が决定されるものとする。をた、通過点の位置べク トルと方向ベクトルにより、

Line at: $2 @ 4 @ 6$ direction: $-3 @ 7 @ 0$

を評価すれば、

$$
\mathrm{z}=6,(\mathrm{x}-2) /-3=(\mathrm{y}-4) / 7
$$

が得られる。とてで、直線オブジェクトがその所在を特定するため に保持すへき必要十分な情報とは、いずれの昜合においても通過点 の位置ベクトルおよび内部的に変換された方向ベクトルの二つのみ であり、前者 (1) の場合には、

Line at: point1 direction: point 2 - point 1

へと単に変換するだけでよいととは自明である。以上はべクトルを 拠り所に值線オブジェクトを生成する手続きの最も初歩的事例であ り、直線を特定する方法は他にも様々な幾何オブジェクトを执り所 K生成する方法が多数考えられる。しかし、いずれの場合において も直線オブジェクトが一意の空間図形として特定されるために必要 十分な情報は上記の二つのベクトルである。

一方、平面は、通過点の位置ベクトルと法線ベクトルを指示し た、

Plane at:3@6@4 normal:2@-4@3

を評価して、

$$
2 \mathrm{x}-4 \mathrm{y}+3 \mathrm{z}+6=0
$$

なる平面オブジェクト(インスタンス) がその㞍り值として生成さ れる。平面を特定する方法は他にも、最も CAD・CGで一般に用 レられるような通過する 3 点の位置べトルKよる指示方法を用 レれば、
Plane a.t: $1 @ 0 @ 0$ and: $0 @ 1 @ 0$ and: $0 @ 0 @ 1$

なる記述文より、

$$
x+y+z-1=0
$$

が得られる。しかしGDLで㤌、一般の CAD・CGシステムが 3 点の坐棒値を直接・間接的に保持するのとは対照に、平面オブジェ クト (9) は既に (8) における3 点を保持しておらず、インスタンス 生成の過程で平面を特定するために必要十分な法線ベクトルと定数 一と翻訳される。これは、平面を通過点の集合により表現する既存 のモデルと比較して情報量が少なく、平面の延長性を的碓に表現し ていると言える。また、次の章で述べるよな関数レベルでの様々 な幾何的操作を施す場合にも取り扱い安い。逆に、3点として指 示される領域を明示寸る必要があるのであれば、面(Face) として 表現すればよい。

一般に球面や回転体を 3 次元モデル(サーフェスモデル)で取り 扱与場合、分割数を指定することで構成面に分解し、多面体に近似 する方法が一般的に用いられている。てれは形態のグラフィック表 示には效率的な表現であるが、幾何本来の意味は消失していると 言わざるをえない。一方、同じ 3 次元モデルでもブリミティブに よる表現は幾何的ではある。しかし、てれは形態の境界特性がグラ フィックモデルとして採用できることによるすので、幾何的意味を 表現するととを意図したものではない。GDLでは、球面は位置べ クトルと半径により、

Sphere center: 1 (a) -1 (a) 0 radius: 1

を評烌することにより、

$$
(x-1)^{\wedge} 2+(y+1)^{\wedge} 2+z^{\wedge} 2=1^{\wedge} 2
$$

として示される球面オブジェクト (インスタンス)として生成され るが、その内部構造は単純に(10)による指示をそのまま保存した オブジェクトである。

一方、頂点 (vertices) を基準に定義される空間幾何オブジェク トも必要である。例えば線分 (Segment) は、

Segment from: 0 @ 0 @ 0 to: 1 (a) 1 (G) 1

を評価することにより、円弧 (Arc) は

Arc from: 1 @0 @ 0 to: 0 @ 1 @ 1 center: $0 @ 0 @ 0$ (13) を評価するてとにより、それぞれのインスタンスを得るてとにな る。てれらのオブジェクトは、基本的にクラフィックライブラリに 用いられるむのと等洒である。

\section{5. 空間幾何オブジェクトの操作}

建築デザインを蘩成する空間幾何オブジェクトは、様々な幾何 的操作の結果として作り出される。その具体的手続きは、今日の $\mathrm{CAD}$ ・CG システムにおいては一般にコマンド群として用意され ているが、そのロジックは既存システムにおける幾何オブジェクト の内的表現を反映し、「幾何的操作の絬果として新をな空間幾何オ ブジェクトを得る」といらより、「個別の坐標值を計算して幾何的 操作と同値とする」といら方法論が主流である。一方、設計思考に 
おいて一般に幾何的知識をどのよらに利用しているかを考えた昜 合、幾何オブジェクトは全て幾何オブジェクトレベルで抽象的に処 理されるものであり、具体的座標值に還元して計算されている訳で はない。ここて、、幾何学の方程式を解くのと同様の、素直な形での 空間幾何オブジェクトの操作の表現を試みる。

建策設計プロセスにおいて、ある平面に平行で適当な距離だけ離 れた平面を想定することは頻繁に行われる行為であるが、GDL K おける平面オブジェクトの操作では、例えばそれぞれを plane1。 plane2 とすると、

| plane1 plane2 |

plane1 := Plane at: $3 @ 6$ @ normal: $2 @-4 @ 3$

plane $2:=$ plane1 translatedBy: 10 .

を評価するととにより plane2 は、

$$
2 x-4 y+3 z-47.8516=0
$$

としてインスタンス生成される。ててで重要なのは、先に述べよ らK、生成される plane1 が数学的関数を㧋り所とした内部表現て ある点である。つまり、 plane1 は生成の過程で参照した位置べク トル $(3 @ 6 @ 4)$ を保持していないため、plane2 が既存のグラ フィックライブラリにおけるような、 plane1 Kおける特定の頂点 の平行移動により求められるものではないととである。また、建築 における柱の軌道は一般に二つの通り心 (平面)の交線として意図 されるものであるが、三つの平面の交差部分としての直線を求めよ 5とする場合、それぞれを plane1・plane2。line1 とすると、

| plane1 plane2 line1 |

plane1 := Plane at: $0 @ 1 @ 0$ normal: $1 @ 1 @ 1$.

plane2 :=Plane at: $1 @ 0$ @ normal: 2 @ 1 @ 1 .

line1 := plane1 intersectionWith: plane2

を評価するととにより line1 は、

(x) $/ 2=(y+(1 / 2)) / 1=(z-(3 / 2)) /-3$

としてインスタンス生成される。その内的処理手続きは、二つの平 面関数による連立方程式を解くことであり、具体的には平面の法線 ベクトルの外積により条件分割して求められるてとは代数幾何学の 初歩である。さらに例えば、值線と等間の一点を通る平面を求めよ らとする場合、それぞれをline1。point1・plane1 とすれば、

| point1 line1 plane1 |

point1 :=0 @ $-1 @ 1$.

line1 := Line at: 0 @ 0 @ direction: $1 @ 1 @ 1$.

plane1 := line1 interconnectionWith: point1.

を評価するととにより plane1 は、

$$
2 \mathrm{x}-\mathrm{y}-\mathrm{z}=0
$$

としてインスタンス生成されるが、てれもその内部手続きは同等の 幾何問題を代数的に解く手続をと等価である。

このよらK、GDL が行ら具体的手続きは全て幾何オブジェクト レベルで数式的に処理されるものであり、頂点の座標值に還元して
計算されるものではない。単に、初等代数幾何における知諳をを゙の まま素直に記述したにすを゙ない。

\section{6. 幾何的決定のモデル化}

設計のダイナミズムを考える場合、空問幾何オブジェクトが数式 レベルで表現されたり操作されているだけでは不十分である。なぜ なら先に示した Line や Plane などの演繹的に生成された幾狗オブ ジェクトそれ自体はベクトル空間内において静的構造を持次幾何 的决定の結果であり、設計における幾何的决定を直接表琹するも のではないからである。設計における幾何的決定とは、てれら幾 何オブジェクトを生成する手続きそのものであり、GDLではてれ を幾何的決定オブジェクト (aGeometricDecision) として導入す る。つまり、建築設計における幾何的决定プロセスは、幾何的决定 オブジェクトの決定木(ネットワーク)として表現されるてとにな る。

幾何的决定オブジェクトは、それ自体が幾何的図形を直接示すの ではなく、それを導出する手続をを変数として保持するオブジェ クトであり、親 (parents)、コンテクスト (context)、子 (dependent)、および現在幾何 (currentGeometric) といら属性により表 現可能である。親は文字どおり、その幾何的决定オブジェクトを生 成する際㑢照した、基となる幾何的决定オブジェクトを你存する 変数である。コンテクストは忙その生成手続きそのものをデータと して保存する変数であり、具体的に Smalltalk 言語ではブロック 注8）と呼ばれる構造で表現される。手続きを大括弧 []で田むとと で指示されるブロックは、手続きの棈造自体をデータとして保持す る特殊なオブジェクトとしてインスタンス生成されるが、その手続 き自体は生成時点では評洒されない。例えぱ、 $[x+y]$ として 記述されるブロックは、 $x$ と $y$ を足すといら手続き自体をデータ として保持したオブジェクトであり、その具体的值は、それが評価 される時点での $x$ と $y$ の值に依存する。子は、その幾何的決定才 ブジェクトを親として指示している幾何的炔定オブジェクトを保持 する変数である。現在幾何は文字どおり、コンテクストを言価した 結果としてインスタンス生成される最新の空間幾何オブジェクトを 参照する変数である。

GDLにおいては、人工知能向言語が手続きをデータとして取り 扱えるといら特徵を利用し、幾何的决定オブジェクトの生成手続き を settled タッセージとして実装した。 settled メッセージは、空 間幾何オブジェクトに送信するととにより、その空間幾何オブジェ クトを生成する最も単純な手続きをコンテクストK保持しそ:幾何的 决定オブジェクト一と昇格させる。また、幾何的决定を操件するブ ロトコルは、空間幾何オブジェクトを操作するプロトコルと同じで ある。例えば、先の二つの平面を設定し、これらの交差部兮として 直線を定義するプロセス (16) は、以下のよらに記述でをる。

| decision 1 decision 2 decision 3 |

decision $1:=($ Plane at: $0 @ 1$ (a) 0 normal: $1 @ 1 @ 1)$ settled.

decision $2:=$ (Plane at: $1 @ 0 @ 0$ normal: $2 @-1 @ 1)$ settled.

decision $3:=$ decision 1 intersection With: decision 2 . 
こてで decision 1 はべクトル空間の基準点 $(0 @ 0$ @ @ 0) を親とし て参照し、[Plane at: 0 @ 1 @ normal: 1 @ 1 @ 1] とレらブ ロックをコンテクストとして持つ幾何的决定オブジェクトとして、 decision2 は [Plane at: 1 @ 0 @ 0 normal: 2 @-1@1] とい5 ブロックをコンテクストとして持つ幾何的決定オブジェクトとして 生成されることになる。また、(16)では intersectionWith: とよ り、 line1 K具体的な值線のインスタンス (17) が直接生成された が、 decision 3 では、親は decision 1 と decision2であり、コンテ クストは[decision1 intersectionWith: decision2]とレらブロッ クそれ自体となる。そして、生成直後の現在幾何は、

$(\mathrm{x}) / 2=(\mathrm{y}+(1 / 2)) / 1=(\mathrm{z}-(3 / 2)) /-3$

と、(17) と同值となる。

一方、てれらは生成手続きによる幾何的决定として定義している ため、親となるオブジェクトにおける何らかの㚆化は、即座に自身 の変化の引き金となる。つまり (20)での直線 (decision3) は、あ くまで平面 (decision1) と平面 (decision2) の交差部分として定義 されているために、平面 (decision 1) が移動すれば、その結果とし ての直線 (decision3) は応分の影響を受けるととになる。例えば、

decision1 moveBy: (4@1 @ 3) settled

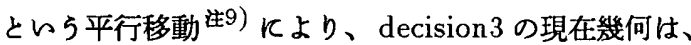

$(\mathrm{x}) / 2=(\mathrm{y}-(7 / 2)) / 1=(\mathrm{z}-(11 / 2)) /-3$

へと変化することになろう。この変更は平面の移動に伴い瞬時に 起こるべきであり、実際にはこの制約伝播に依存性メカニズム文2) の考え方を応用する。依存性メカニズムでは、自身が何らかの幾何 的変更を受けた場合に、変更が行われた旨を changed: メッセージ として自身に送信する。それぞれの幾何的决定オブジェクトは訨 存関係にあり挙動を調整しなりればならない幾何的决定オブジェ クトの集合を子として保持しているため、changed: メッャージで は、それらに update: メッセージを一斉送信する役割を果たす。 update: メッセージを受け取った幾何的决定オブジェクトは、改め てコンテクストを評価するととにより、自身の幾何的表現の一貫性 を保証する。

また、平面 (decision1) と平面 (decision2) の交線として求めた decision 3 自身をさらに移動した場合には、

decision3 moveBy: (3 @ 4 @ 5) settled

と記述されるが、これが実行された decision 3 のコンテクストは [[decision1 intersectionWith: decision2] moveBy: 3 @ 4 @ 5] といら入れ子構造のブロックを值として取ることになる。てれによ り、幾何的决定オブジェクトの現在幾何を更新する場合には、単に コンテクストを訣価するといらシンブルな構造で実現するととが可 能となる。

\section{7. 考察}

本論文で示した GDL が想定する空間幾何オブジェクトの表現 は、数学的定義を素直にオブジェクト構造に投影した結果である。 一方、このよらな空間幾何オブジェクトの表現には限界があるとと も事実である。一般に、関数的記述で簡便に表現できる空間幾何図
形には限りがあり、建築形態の自由度といら観点からの限界が指 摘されるかもしれない。しかし、自由な形態表現とそは既存のグラ フィックライブラリが対応する領分であり、GDL が扱らべきは具 体的な建築形態の記述ではなく、設計プロセスにおける形態の秩序 としての幾何であると考える。

GDL を具体的 CAD システムK適応する場合、例えば上記の枠 組みの中で AKM Kおける階 (aFloor) を定義する手続きは、

| decision 1 decision 2 floor1 floor2 | decision $1:=$ Plane $x y$ Plane settled. decision $2:=$ decision 1 translatedBy: (0@ 0 @ 3600) settled. floor $1:=$ Floor supportedBy: decision 1. floor2 := Floor supportedBy: decision 2 .

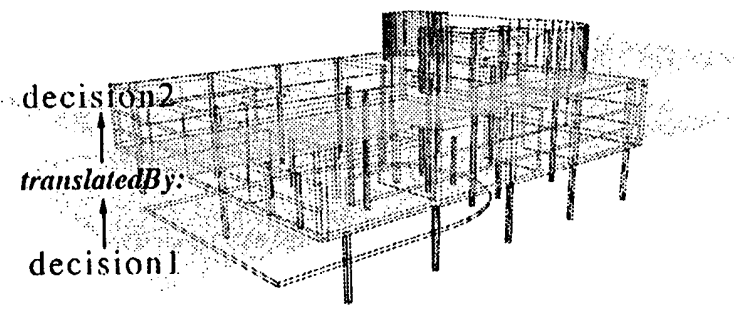

図 1

のように記述でをる。こてで、それぞれの階を支えるオブジェクト は、幾何的决定オブジェクトのインスタンスであり、決定相互の間 には translatedBy：とい5制約が存在するととになる。あるいは 二つの通り心 (decision1, decision2) の交線 (decision3) を軌道と する柱 (aColumn) を定義する手続きは、

| decision 1 decision 2 decision 3 column1 | decision $1:=($ Plane $x z$ PlaneAt: 1200) settled. decision $2:=$ (Plane yzPlaneAt: 2300) settled. decision $3:=$ decision 1 intersectionWith: decision 2 . column $1:=$ Column 1 supportedBy: decision 3 .

と記述されよう。

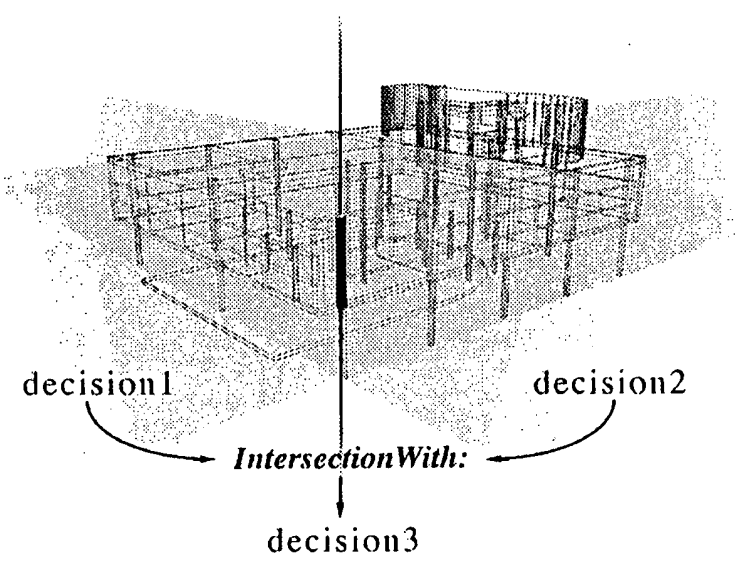

図 2 
一方、入れ子構造のコンテクストはオブジェクト単位での決定の 履歴が簡単に記述できるが、設計プロセスの進行の中で発見される 等価でより単純な㚆換に還元するには、ヒューリスティックな知識 を導入する必要むあり、今後の課題である。

なお、GDL の実装はVisualWorks 環境上に構筮されているた め、Smalltalkの仮想計算機が提供されている様々な計算機環境 下で実行可能であり、そのソースコート゚はインターネット上に公開 している (http://gaudi.sk.tsukuba.ac.jp/)。また、本ライブラ リを用いて実際に構築した CAAD システムの詳細については、次 稿に譲る。

本研绝は 94 年度および 95 年度の文部省科学研觉費助成を受け て行なわれた。また、その一部は 1994 年度九州支部研究報告会 (日本建築学会)文13) および CAAD Futures'95(国際会議)文14) に て発表されたものであり、本論文はその後の研究を踏まえて加執修 正したものである。

注

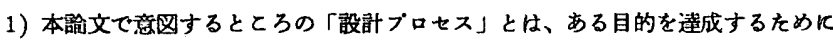

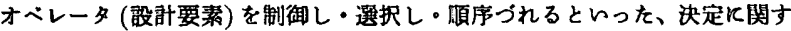
る”時間的”槏相である。文 1,7$)$

2）オブジェクト指向とは、データのは加にて手続き(プロクラム)をバックー シ化したあのをオブジェクトとしてとら六、オブジェクト同士がメッセージを

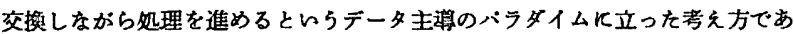
り、それを具体的烧表見する手段としてデータ抽象・インーリタンス(クラス 㳻冏曙造)・ボリモルフィズムなどか要求される。文 3,8$)$

3）建筑分野では、古くはスケッチバッド(長潘勳他)、DELTA(三菱地所)、 LORAN-T(大成建設)などが上げられる。また、最近ではではAIAによる IFC(Industry Foundation Classes) などの動をある。

4）本章て意図するとてろの「デザイン」とは、建筇要素の意匠的・形態的構成あ るいはその記述である。

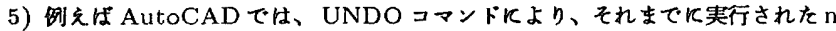
回のコマンド㙅作を取り消し、n回前の状態に杘るととができる。

6) Smalltalk は、オブジェクト指向のコンビュータ言語である。クラスは大文 字で始まるシンボルで表現され、記述文頭の|....|は一時妢数の宣言である。 登数にはオブジクトが代入され、:ニが代入記号である。オブジェクトに続
くシンボルがメッセージであり、メッセージが引数を持つ場合にはシンボルの 最後に: 胕加され、それに続くオブジェクトがメッセージの引数として扱わ れる。文2)

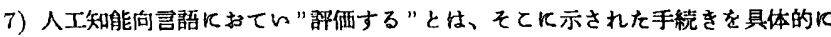
実行し、具体的值(インスタンス)を得るととである。

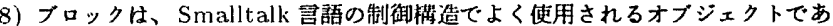
り、一連の処理を奏行しない状態のままにしておきたい場合に用的る。文2）

9) GDLでは、moveBy: は幾何的操作Kよりそのオブジェクト自身を更新する 手続き、translatedBy: は幾何的操作により新しレオブジェクトを生成する 手続をとして、区別している。

\section{考文献}

1) Simon,H. : The Sciences of the Artificial, MIT Press, 1967

2) Goldgerg,A. and Robson,D. : Smalltalk-80 The Language and its Implementation:, Addison Wesley, 1985

3) Cox,B.J. : Object Oriented Programming : An Evolutionary Approach, Addison Wesley, 1986

4) Walfram,S. : Mathematica - A System for Doing Mathematics by Computer-, Addison Wesley, 1988

5) 吉川弘之、富山整男：インテリジェント CAD(上)，浅倉書店，198؟

6) Gross,M.D. : Relational Modeling: A Basic for Computer-4ssisted Design, The Electronic Design Studio -Architectural Knowledge and Media in the Computer Era-, MIT Press, 1990

7) Coyne,R., Rosenman,M., Radford,R., Barachandran,M. and Gero,J. : Knowledge-Based Design System, Addison Wesley, 1990

8) Code,P. and Yourdon,E. : Object-Oriented Analysis, Yourdon Press, 1990

9) Mitchell,J. : The Logic of Architecture, MIT Press, 1990

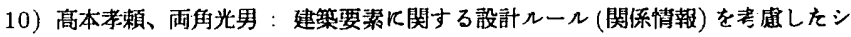
ステムの試作とその訐価、日本建策学会計画系踚文集 第 441 号、 $1 \leqq 92$

11）渡辺伿、渡辺化：建策設計のための知識表現モデルに関する研究、日本建策 学会部画系論文集 第443号、1993

12) Carrara,G. and Kalay,Y.E., eds. : Knowledge-Based ComputerAided Architectural Design, Elsevier, 1994

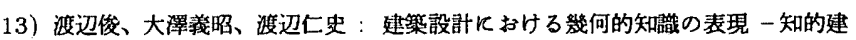
策 CAD のための空間郡述言語の開発一、九州支部研究報告会、 $19 \subseteq 5$

14) Watanabe,S. : Representing Geometric Knowledge in Architectural Design, CAAD Futures '95, 1995 